INTERNATIONAL JOURNAL OF RESEARCHES IN BIOSCIENCES, AGRICULTURE AND TECHNOLOGY (C) VISHWASHANTI MULTIPURPOSE SOCIETY (Global Peace Multipurpose Society) R. No. MH-659/13(N) www.vmsindia.org

\title{
PREVALENCE OF LEPROSY IN TRIBAL AND NON-TRIBAL AREAS IN VARIOUS DISTRICTS OF MAHARASHTRA STATE
}

\author{
S. S. Nimgare ${ }^{1}$, U. W. Fule, A. S. Patankar and P. M. Telkhade ${ }^{3}$ \\ ${ }^{1}$ Hutatma Rashtriya Arts and Science College, Ashti. Dist. Wardha. \\ ${ }^{2}$ Mahatma Gandhi Ayurved College, Salod, Dist.Wardha. \\ ${ }^{3}$ Arts, Commerce and Science College, Tukum,Di. Chandrapur. \\ patankar.kargi@gmail.com
}

\begin{abstract}
:
The present study was carried out to study the prevalence of leprosy in tribal and non-tribal areas in various Districts of Maharashtra State. In the present investigation prevalence of leprosy was found more in tribal areas than non-tribal areas of Maharastra state. New Case Detection Rate (NCDR/lac) of leprosy was found highest in tribal (68.10/lac) and non-tribal (23.50/lac) areas of Gadchiroli District while population Rate / 10000 was found higher in tribal areas (3.23/10000)of Gadchiroli District and non-tribal areas (1.44/10000) of Chandrapur District. Prevalence of leprosy in child was observed more in tribal areas $(13.60 \%)$ and non- tribal areas $(21.42 \%)$ of Thane District. Prevalence of leprosy regarding NCDR/lac was found lowest in tribal areas (1.80/lac) of Amravati and non-tribal areas (0.00/lac) of Nandurbar District. Population Rate/10000 was found lower in tribal areas (0.00/10000) of Amravatiand non-tribal areas (0.00/10000) of Nandurbar and Gadchiroli District. Lowest \% of child leprosy was observed in tribal areas $(0.00 \%)$ of Amravati and Ahmadnagar and non-tribal areas $(0.00 \%)$ of Nandurbar and Gadchiroli District.

Keyw ords: Prevalence, Leprosy, Tribal, Non-tribal, Districts,Maharashtra State.
\end{abstract}

\section{Introduction:}

Leprosy is a chronic infectious disease caused by Mycobacterium leprae. It affects mainly the peripheral nerves, skin and occasionly the mucosa of the respiratory tract. Of all communicable diseases, leprosy is most important for its potential to cause permanent and progressive physical disability. In addition, the disease and its visible disabilities in particular, contribute to intense social discrimination of patients.

About $69 \%$ of the leprosy cases in the world are found in India. For every 10,000 population there are about two leprosy cases (prevalence $=1.3$ per 10000 as on March 2005) in India. The new leprosy cases detected in India (year 2004-2005) were 260063.

The present study deals with prevalence of leprosy in tribal and non-tribal areas in various Districts of Maharashtra State.

\section{Methods of Leprosy Detection:}

Leprosy is caused by a bacteria Mycobacterium leprae(Fig.-1)..It is strongly acid fast (it is stained red by a dye called carbolfuschin and the red colour cannot be removed either by acid or alcohol). The presence of the bacilli can be demonstrated by taking smears from skin/nasal mucosa (slitting the skin and scraping the material with blade and spreadind it on a glass slide, staining it with the ZiehlNeelsen method and examining under the microscope ). Usually skin smear in leprosy is taken from three sites ( skin lesions, both ear lobes). The smears may be either positive or negative for M. leprae. Leprosy patients whose smears are positive are more infectious than those who are not.

The prospective study was undertaken with NLEP- GOI for the year April 2007 to March 2008 to detect leprosy cases in various Districts of Maharashtra State

\section{Result and Discussion:}

In the present investigation prevalence of leprosy was found more in tribal areas than non-tribal areas of Maharastra state. New Case Detection Rate (NCDR/lac) of leprosy was found highest in tribal $(68.10 /$ lac) and non-tribal (23.50/lac) areas of Gadchiroli District while population Rate / 10000 was found higher in tribal areas (3.23/10000)of Gadchiroli District and non-tribal areas (1.44/10000) of Chandrapur District. Prevalence of leprosy in child was observed more in tribal areas (13.60 $\%)$ and non- tribal areas $(21.42 \%)$ of Thane District(Table-1).

Prevalence of leprosy regarding NCDR/lac was found lowest in tribal areas $(1.80 /$ lac) of Amravati and non-tribal areas $(0.00 /$ lac) of Nandurbar District. Population Rate/10000 was found lower in tribal areas (0.00/10000) of Amravatiand non-tribal areas (0.00/10000) of Nandurbar and Gadchiroli District. Lowest \% of child leprosy was observed in tribal areas $(0.00 \%)$ of Amravati and Ahmadnagar and non-tribal areas $(0.00 \%)$ of Nandurbar and Gadchiroli District(Table-1).

Prevalence of non-tribal leprosy was related with Urbanization and Industrialization led to rising slum population. State of Maharashtra has $42.4 \%$ urban population of 
which $40 \%$ stays in slums. There were 3 cities with population of $>25$ lakh each, 10 cities with population between 5 to 25 lakh and 26 cities with population 1 to 5 lakh, 22 Municipal Corporations and 224 Municipal Councils in the state.Most of the urban area lacked health infrastructure resulting into congregation of cases especially in slums. Poor voluntary reporting had been observed in these areas as a result of delayed integration of NLEP in GHC. There was poor involvement of Private Practitioners. At the time ofstudy there were 15 tribal Districts in the state with remote, hilly, unapproachable areas having diversity in tradition, language, literacy etc. Tribal people harboredmisconcepts, taboos etc. regarding leprosy and have faith in traditional medical practitioners. Prevalence rate of leprosy in the tribal population was higher viz. 10,000 population as compared to non-tribal $p$ opulation in the state reaching leprosy elimination.

The results of present study showed that though leprosy control started with the use of multi drug therapy (MDT) for last three decades, however a parallel drop in the incidence or new case detection rate (NCDR) had not occurred (NLEP Report, 2007 ). From 1994 through 2011, more than 100,000 new cases were detected annually, of whom maximum case load was from India.

Efforts had been made to reduce deformities through early detection, self care, physio-therapy and reconstructive surgery particularly for the treatment of nerve damage in leprosy (Van Veen et. al., 2009). Penna et, al.(2005) and Walker et. al. (2007 ) studied the role of thalidomide in the treatment of erythema nodosumleprosum . Aberdein and Singer (2006) also studied the use of corticosteroids in leprosy infection. Evaluating the role of immunotherapy and immunoprophylaxis would also lead us to better understanding of their mode of action. Further molecular analysis of Mycobacterium leprae genome might provide the requisite basis for all this.

\section{Conclusion:}

Prevalence of leprosy was observed more in tribal areas than non- tribal areas. So special efforts are necessary to attack the problem of leprosy in tribal area in the post elimination era.Massive health education drive in these districts using pictorial IEC material in local language along with improvement in case detection and other components of the programme are essential.
Table-1: Tribal and Non-tribal Districts performance in 2007-2008-

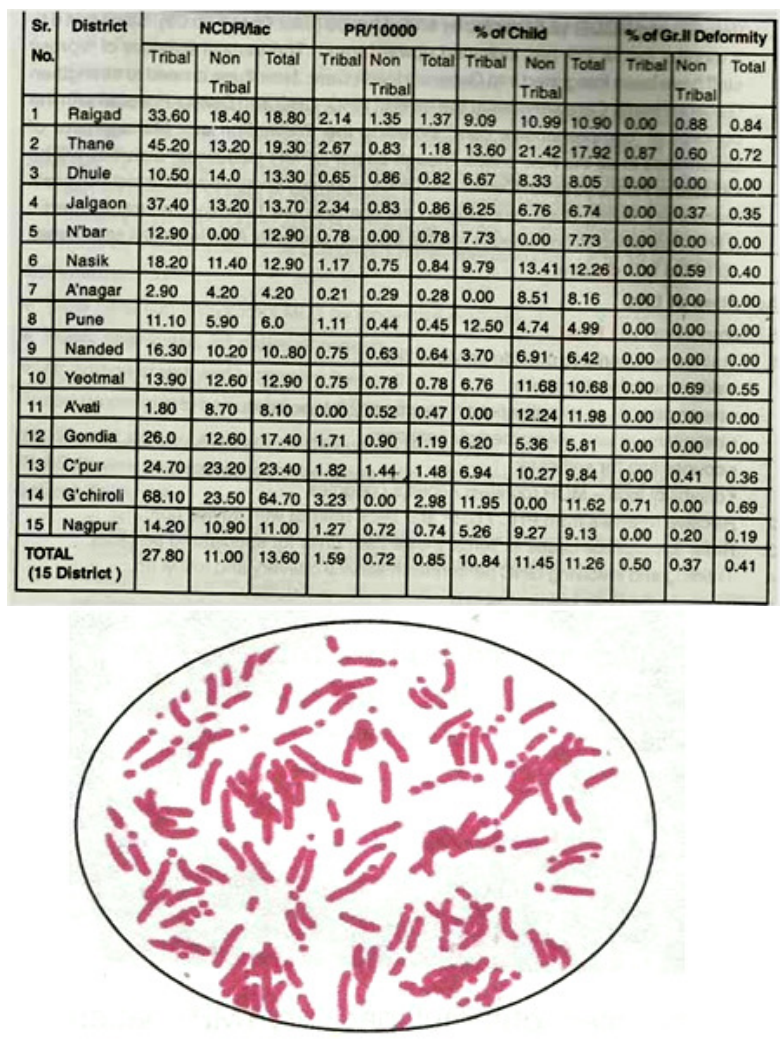

M. leprae under microscope.

Figure.-1: Mycobacteriumleprae.

\section{Acknowledgement:}

$\begin{array}{ccc}\text { Authors } & \text { are thankful to } \\ \text { NLEPDepartment, } & \text { Amravati } & \text { District for }\end{array}$ providing essential material for this study.

\section{References:}

Aberdein, J. and Singer, M. (2006). Critical review : A systematic review of corticosteroid use in infections. Critical Care .10 203 (available online

from

http://ccforum.com/content/10/1/203).

Heijnders, M. and Van Der Meij, S. (2007).The fight against stigma an overview of stigmareduction strategies and interventions. Psychology, Health and Medicine. 113 pp.353363.

Moet, F. J., Meima, A., Oskam, L. and Rechards, J. H. (2004). Risks factors for the development of clinical leprosy among contacts and their relevance for targated interventions. Leprosy Review 75 pp.310-326.

Nicholls, P.G., Ross, L., and Smith, W. C. S.(2006). Promoting early detection in leprosy: A literature review to identify proven potential interventions in addressing patient related delay . Leprosy Review. 77 pp. $298-310$. 
NLEP- Programme Implementation Plan (PIP) for continuation of NLEP (from 1st April 2005 to 31st March 2007)- Ministry of Health \& Welfare, Government of India.

Penna, G. O.,Martelli, C. M. T., Stefani, M. M.A., Macedo, V. O., Maroja, M., and Chaul, A. (2005). Thalidomide in the treatment of erythema nodosumleprosum (ENL) : Systematic Review of clinical trials and prospects of new investigations. Anais Brasileiros de Dermatologia. 80 5pp. 511-522.

Reinar, 1. M.,Forsetlunde, L., Bjorndal, A. and Lockwood, D. (2009). Interventions for skin changes caused by nerve damage in leprosy (Review).The Cochrane Library 2009 Issue 2.
Literature. International Journal of Leprosy and Other Mycobacterial diseases. 71 3pp.190-197

Van Veen, N. H. J.,Schreuders, T. A.R., Theuvenet, W. J., Agrawal, A. and Richards, J. H. (2009). Decompressive surgery for treating nerve damage in leprosy .(Review) The Cochrane Library 2009 Issue 2.

Velema, J.P., Ebenso, B. and Fuzikawa, P. I.(2008). Evidence for the effectiveness of rehabitation in the community programmes. Leprosy Review. 79 pp. 65-82.

Walker, S.L., Waters, M.F.R. and Lockwood, D.N.J. (2007). The role of thalidomide in the management of erythema nodosumleprosum. Leprosy Review 78 pp. 197-215.

Van Brakel, W. H. (2003). Measuring leprosy stigma- A Preliminary Review of the Leprosy 